\title{
'A box of chymical medicines': an Italian medicine chest presented to Sir John Clerk of Penicuik in 1698
}

\author{
${ }^{1} \mathrm{H}$ Dingwall, ${ }^{2} \mathrm{P}$ Worling \\ ${ }^{1}$ Honorary Lecturer, School of Arts and Humanities, University of Stirling; ${ }^{2}$ Life Vice President, British Society for the History of Pharmacy
}

\begin{abstract}
In December 1698 Sir John Clerk, second baronet of Penicuik, visited Cosimo III of Medici, Grand Duke of Tuscany, while on his Grand Tour of Europe - an essential part of the broader education of the gentleman at this time. The Duke presented him with a wooden medicine chest, in which the original medicines in their labelled containers are still to be found. The chest is Italian in origin, but many of the preparations it contains existed in various forms in European - including Scottish - formulations from that time. This paper outlines the context of the period, the state of medicine and pharmacy in Scotland, and examines the contents of the box. It is rare for such a complete chest to survive from this period in Scotland most surviving examples date from at least the mid-eighteenth century. It offers a unique opportunity to investigate some of the medicines of the period.
\end{abstract}

Correspondence to $\mathbf{P}$ Worling 29 Fernielaw Avenue, Edinburgh EHI3 OEF

Tel +44 (0) I3 I $44 I 5 I 34$

e-mail p.worling@virgin.net

KEYWORDS Clerk of Penicuik, medicine chest, Scotland, Italy, pharmacy, Grand Tour

DECLARATION OF INTERESTS No conflicts of interest declared.

\section{INTRODUCTION AND HISTORICAL CONTEXT}

Medicine in Scotland at the end of the seventeenth century was in a state of transition, but also of continuity. Physicians and surgeons had corporate organisations to maintain standards and oversee practice, but these were only found in the largest towns. In more rural parts not much had changed; in all areas a complex combination of beliefs and traditions continued to inform medical practice, as it had done for centuries. ${ }^{1,2}$ Belief in witchcraft and the supernatural was not at all at odds with the new study of anatomy or the beginnings of the medical profession. People consumed medicines from all sorts of practitioners. Medical philosophy was still mainly humoral in focus, though there was ongoing debate on new explanations for the structure and function of the body. Humoral medicine was based on the belief that disease was caused by some imbalance in the four bodily humours - blood, yellow bile, black bile and phlegm. It was also closely linked to the seasons and to astronomical signs. Cures were normally effected by purging the body of 'evil' substances and rebalancing the humours by means of tonics and restorative concoctions. Popular medicines were circulated around landed estates. Many outlandish ingredients continued to be prescribed by practitioners in all parts of the medical marketplace. Gentry families consulted the most prominent physicians and surgeons, but also made up medicines for themselves and diagnosed their own conditions. The medical context at the time was therefore one of interacting spheres of influence, with some elements of transformation, but also much that remained unchanged. In general, the medicines consumed by Scots were largely plant or mineral based but with a gradually increasing number of chemical preparations. It seems that chemical medicines were slower to appear in Scotland than in England, though the reasons for this are not clear. Medical practice in early modern Italy was similar, though heavily influenced by royal or ducal physicians and surgeons, and, in Naples, by the Protomedicato, a committee headed by the Royal physician. ${ }^{3}$

Generally, although the pace of urbanisation was accelerating, Scotland was still largely rural in nature and in most areas the landed gentry continued to hold positions of influence. Scotland was, in many ways, more closely linked to Europe than to her southern neighbour. Scots had traded in Europe for centuries and Scottish students, including medical students, studied at many European universities. The Grand Tour was an essential part of the broader education of the gentry, and it was customary to spend a considerable amount of time on this exercise. ${ }^{4}$

\section{THE CLERKS}

The Clerks of Penicuik were not at the highest social level; they were a product of the growing mercantile and proto-industrial sector of late seventeenth-century society. The barony lands of Penicuik, some ten miles south of Edinburgh, had been purchased by John Clerk the elder (1611-74) in 1646 after he had built a successful career as a merchant. The first baronet, John 
Clerk (1649/50-1722), succeeded his father as Laird of Penicuik in 1674, extended the family landholdings and exploited their coal reserves. He was created baronet in 1679.5 His son, John Clerk (1676-1755), who would become the second baronet, studied at the University of Glasgow and was then sent to undertake legal studies in Leiden, where he struck up a friendship with Hermann Boerhaave, one of the leading physicians of his day. After his return to Scotland, Clerk still consulted Boerhaave on medical matters affecting his family.

Clerk left Edinburgh in October 1694 and remained in Holland until May 1697, when he left for Italy, on a typical Grand Tour of the time, visiting Vienna before heading for Venice and then Rome. His lengthy return journey to Scotland included visits to Florence, Pisa, Marseilles, Paris and a further three month stay in Holland, and he eventually arrived home on 6 November, 1699. He therefore received both a professional and a gentleman's education, typical of the time, which would be utilised to the full in his later legal and cultural interests. Clerk became a leading member of the legal profession, served as a member of the Scottish Parliament and was one of the commissioners who negotiated the terms of the Act of Union of 1707, after which he sat in the First Westminster Parliament. He was also a noted musician, composer and collector of antiquities. ${ }^{6}$

During his Italian sojourn Clerk was introduced to many high status individuals by Alexander (Cosimo) Clerk, a former soldier who had taken holy orders and was known as Father Cosimo, having gained the favour and patronage of Grand Duke Cosimo III (1642-1723). Alexander Clerk is variously described as 'cousin', 'uncle' and 'near relation' to John. According to John Clerk's memoirs, Alexander had served as a soldier in Flanders, then taken holy orders as a Franciscan monk. He met the Grand Duke, who 'took a likeing to him... and sent him to Rome to manage some of the Florentine affaires at that Court'. The precise relationship between the two men is not clear, but it seems that the high status which Alexander had acquired was sufficient to gain entry for John to the highest social levels. ${ }^{7}$ In mid 1698 John was received warmly by Grand Duke Cosimo III "with greater marks of distinction than his Highness used to bestow on strangers." It is not clear whether the Clerks had direct contact with the Medicis previously but it is likely that John Clerk had already been introduced by other friends who had connections.

Cosimo III had succeeded his father as Grand Duke of Tuscany and held the dukedom from 1670 to 1723 , the longest reign in Tuscan history. His tenure was blighted however by the deterioration in economic conditions in his territories. The succession passed to his son, but despite representations made by Cosimo during his lifetime, on the death of his son the dukedom was transferred to the House of Lorraine.
On taking his leave of the Grand Duke in December 1698, John Clerk was presented with 'a box of chymical medicines... and with all the variety of wines and sweetmeats which his country produced'. ${ }^{8}$ It was not unusual for gifts, perhaps more often books or objets d'art, to be bestowed on favoured guests. The gift of a medicine chest is perhaps more unusual. ${ }^{9}$ In addition to these material gifts, Clerk was also appointed Gentleman of the Bedchamber to the Grand Duke and was given the assistance of the Duke's 'Great Library Keeper' for his ongoing studies. There is no note in Clerk's diaries of a return gift. This medicine chest is the subject of detailed analysis here.

\section{MEDICINE CHESTS}

Medicine chests generally became available in Britain from the mid-eighteenth century. They were made usually by skilled carpenters, who also produced fine mahogany writing slopes and boxes. These were often handsome pieces. The boxes were stocked by pharmacists and wholesalers before being supplied to the public, and ranged from simple boxes to more elaborate folding cabinets, and also much larger cabinets, which were intended to be used by medical practitioners in their consulting rooms. Wholesale production of medicines was not common in late seventeenth-century Scottish medicine - most pills and potions were still made up by apothecaries, though some patent medicines such as Dover's and Anderson's pills were available and advertised widely and enthusiastically in the expanding local and national press.

In Italy however, the Medici family had long pursued interests in chemistry and the manufacture of glass. In the early seventeenth century Grand Duke Antonio de Medici established a laboratory, known as the Foundry, in the Casino di San Marco. ${ }^{10}$ This laboratory was maintained by succeeding Grand Dukes, and it is likely that the majority of the medicines in the Penicuik chest originated from this source.

\section{THE PENICUIK CHEST}

The chest is made of polished wood and measures $26.5 \mathrm{~cm}$ wide, $14 \mathrm{~cm}$ deep and $14.5 \mathrm{~cm}$ high. It is fitted with a lock and metal strap hinges. The lid lifts up to reveal a top compartment divided into eight sections, with space at one end for a decorated tin box (Figure I). Each section has a leaflet describing the virtues of the medicine it contains. In one corner of the top compartment there is a wooden peg which releases a drawer in the bottom of the box that slides out to the side (Figure 2). This lower drawer is divided into ten sections, nine of which hold glass bottles sealed with corks, and the top of each bottle is covered with parchment. As with the upper 


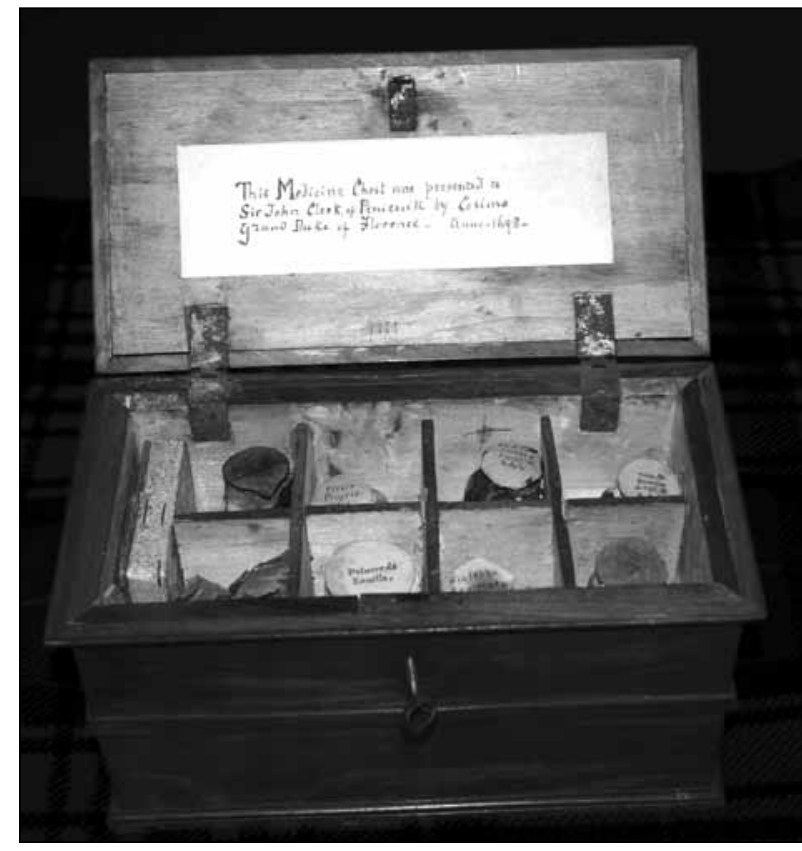

FIGURE I The Penicuik medicine chest showing the upper layer of compartments and their contents.

compartment, each section contains a descriptive leaflet. These leaflets are important, as although each product has been labelled on the parchment cover, with the passage of time together with staining of the tops by the contents in some cases, not all of the labels are legible. The word 'fonderia' (meaning foundry) is used in the title of each medicine. Each printed leaflet has the arms of the Medici family at the top (Figure 3). The heading then gives the name of the product and in most cases this is followed by the words 'Di Fonderia di Sua Altessa Serenissima' (the Foundry of Your Most Serene Highness). In a number of cases the alternative wording 'Di Fonderia del Serenissimo Gran Duca' is used or 'Gran Duca di Toscana'. In the case of one product, acqua triacalle, the name is followed by the words 'della Fonderia del Serenissimo Ferdinando Secondo Gran Duca di Toscana cioe' which would indicate that this particular formula was

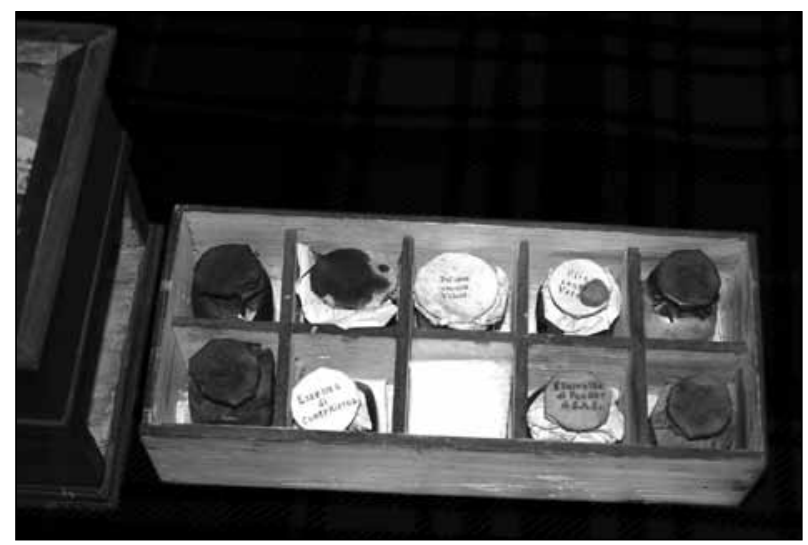

FIGURE 2 The lower segmented compartment and its contents.

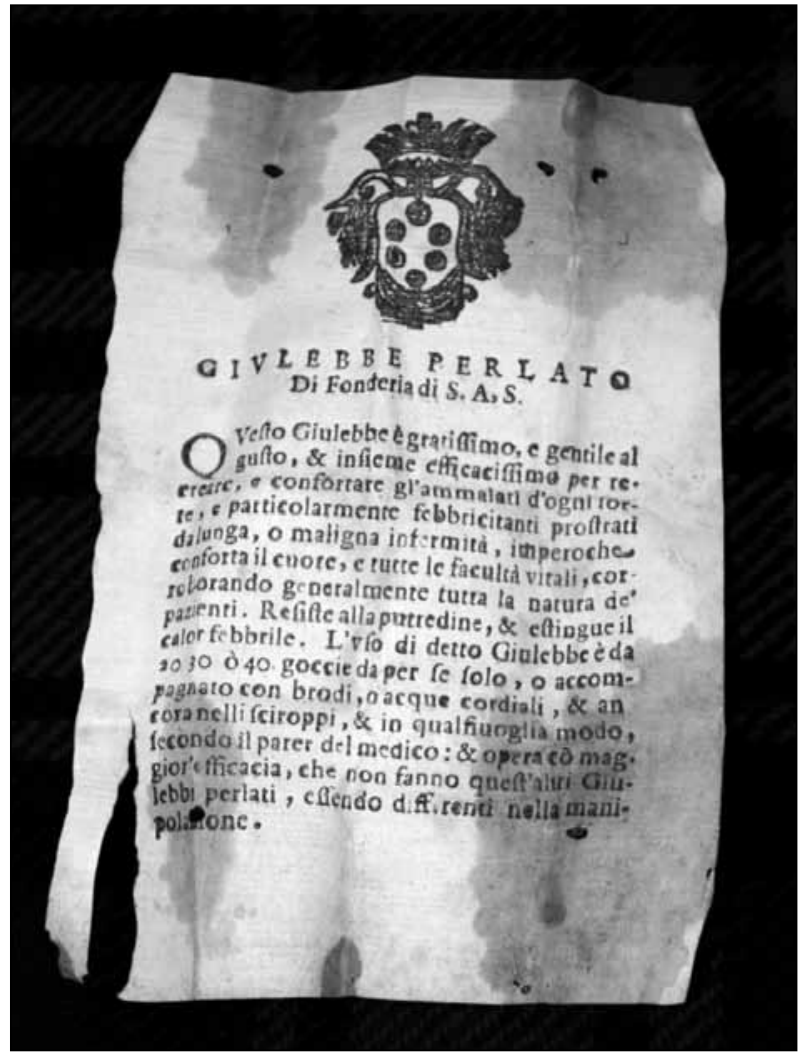

FIGURE 3 An example of an explanatory leaflet; one was included with each medicine.

associated with Cosimo III's father, Ferdinando II. These statements would seem to confirm that the contents were supplied by, and many of the items probably manufactured at, the Foundry.

The following translation of the information about the product giulebbe perlato - pearl julep - provides an example of these leaflets.

This Julep has a very pleasant and mild taste and at the same time is very effective for refreshing and comforting all sorts of ill people and particularly those feverish, exhausted by a long, or malignant illness, because it comforts the heart and all the vital faculties; invigorating all the nature of patients. It resists decay and extinguishes feverish heat. The use of the Julep is 20,30 , or 40 drops on its own, or with broth, or cordial waters and also syrups and in accordance with the physician's advice. It acts more effectively than those other pearl Juleps which are manipulated differently.

It is clear from the descriptive leaflets that those working in the laboratory considered that the recipes from which these medicines were made were their own private formulae, particularly in the case of polvere contro veleni, a secret remedy not available anywhere else. The patient is frequently warned not to accept substitutes and to be careful to look out for counterfeit medicines. 


\section{CONTENTS OF THE CHEST}

The following are descriptions of the 18 items contained in the chest along with the tin containing tablets:

\section{Top compartment}

I. Acqua da petecchie: Distilled water for the treatment of a skin rash or impetigo. Petecchie ('petechiae' in modern medicine) are small haemorrhages just under the skin, but in this case the medicine may have been used for more widespread skin conditions. Differentiation of particular types of disease affecting various parts of the body was also evolving at this time, and the same treatments were often used as general cures for a number of different ailments affecting a particular area of the body.

2. Elixir proprietatis: This was a common preparation, also known as elixir paracelsi or elixir proprietatis paracelsi. It was in use for many years and held in high regard. A formula for making the elixir is given in the Archidoxorum Aureoli Theoprasti Paracelsi of 1570." It contains myrrh, aloes and crocus (saffron). The following extract from a chapter heading in Helmont's Treatise of the Great Antidote of Van Helmont, Paracelsus and Crollius of 1666 gives an indication of the medicine's popularity: 'Known by all physicians to be the greatest cordial and only medicine in the world for long and sound life: restoring nature even at the point of death, and effectually taking away all the seeds of disease'. ${ }^{2}$ This preparation was still included in the British Pharmaceutical Codex in 1923 and 1934 as tincture of aloes and myrrh - the formula was given as 'aloes $2 \mathrm{oz}$, saffron $\mathrm{I} \mathrm{oz}$, and tincture of myrrh $20 \mathrm{fl} \mathrm{oz}$. Macerate for seven days with frequent agitation and then strain.'

The perceived cleansing properties of myrrh and aloes prompted their use during episodes of plague ${ }^{13}$ and they were also used in early modern Scottish medicines. One large consignment of medicinal substances imported by an Edinburgh merchant in 1691 contained aloes and myrrh, while the inventory of William Deans, an Edinburgh apothecary who died in 1736, contained many similar substances, including myrrh, alongside chemical preparations such as oxide of lead, copper sulphate and sulphuric acid. ${ }^{14}$

3. Ess. di contraierva: This is essence of contrayerva, usually prepared as an aqueous or alcoholic extract of the aromatic root of dorstenia contrayerva moracae, a herb found in South America, Mexico and the West Indies. There are many species of dorstenia and in commerce they may have been adulterated. It appears to have been quite well known at this time and must have been imported into Europe from South America. In Loimologia, ${ }^{15} \mathrm{Dr}$ Nathaniel Hodges recommended contrayerva as an anti-epidemic and as a gentle tonic for the treatment of fevers and snake bite, as did other writers at the time. It was also advocated by some authors for the treatment of measles, small pox, scarlatina, erysipelas and typhoid.

4. Olio da stomaco: This is an oil for the treatment of stomach complaints. Because it is an Italian preparation it is possible that it consists of olive oil or at least contains it; olive oil has a long history of medicinal use both externally and internally.

5. Acqua da colica: A water to treat colic. This water was deemed to be 'of value against the pain of colic, all accidents of the womb and wind. Two dramme [probably an alternative spelling for 'drachm' - a unit of weight equivalent to 60 grains, or one-eighth of an apothecary's ounce] to be taken with a generous quantity of warm wine.'

6. Poluer da renella: This is read as 'polvere', a powder to treat 'sand' in the kidneys. This refers to the condition urinary tract calculi, which in some instances can have the consistency and appearance of sand.

7. Giulebbo gemmato: This was a well-known remedy. It is a julep or syrup containing precious stones. The use of precious stones in powder form, for the treatment of disease was not uncommon at this time. It was a costly treatment so it would have been restricted to rich patients and the expense may have helped to increase the patient's belief in its effectiveness. There are a number of different formulae, and notes on the preparation are detailed in the Teatro Farmaceutico of $1681 .^{16}$ This prescription takes two drachms each of topaz, emerald, robini, sapphire, giacinti (hyacinth), sardonyx (onyx) and rose coral which were powdered in a porphyr mortar (porphyr or porphyry is a hard igneous rock, frequently purple/red in colour). The crushed stones were then digested in acid and further treated to prepare the final medicine. Onyx was at one time recommended for increasing stamina and healing lungs and bones. Coral was used as a source of calcium. Coral was still in use in medical products as recently as fifteen years ago. The pharmaceutical company Bristol Myers Squibb produced a chemical called eleutherobin, extracted from a species of coral, which binds protein material within cell structures and is powerfully cytotoxic in vitro.

Surviving records on Scottish medical practice of the time however do not indicate that precious stones were used widely in the preparation of medicines (although lapis lazuli praeparatus was listed in the Edinburgh Pharmacopoeia of 1722). The wealth of the Medicis may have contributed to the use of precious stones in medicine, given that only a limited number of people could have afforded it. In Scotland, precious metals such as gold and silver were used, often to coat pills prescribed to high status patients. 
8. Acqua triocello: Water of theriac. This is a form of theriac or theriaca, a well-known compound medicine of Greek origin. It was considered an antidote to snake bites and a universal cure-all for a multiplicity of ailments including stomach complaints, asthma, jaundice, dropsy, colic, inflammation of the kidneys and bladder, and plague. It was considered to be an improvement on mithridatium, a multi-ingredient confection which was supposed to protect against poisoning (perhaps of particular interest to the Medicis, given their turbulent history and the rumours and accusations of poisoning involving several members of the family). ${ }^{17}$ The formulation contained many ingredients and took weeks to prepare. Also manufactured as an electuary (medicinal powder mixed with a syrup), it was sometimes known as Venice treacle, ${ }^{18}$ and it does appear in the Scottish records. The Graeco-Roman physician Galen was reputed to have produced a version with 64 ingredients. The use of multiple ingredients was common at this time and may have been partly an attempt to outdo lay practitioners, who tended to use fewer ingredients, and thus emphasise the greater learning of the qualified physician. Theriac was still accepted as an appropriate medicine in the seventeenth century. ${ }^{19}$ It was well into the eighteenth century before the Edinburgh Pharmacopoeia eliminated many of the more outlandish substances contained in its early editions.

9. Decorated tin box (Figure 4): This contains tablets bearing the crest of the Medici family on one surface and a reference to the Foundry on the other.They are greyish white in colour and resemble tablets of prepared chalk, which would have been used as an antacid for indigestion.

\section{Lower drawer}

10. Olio balsamo per libachi: This is an oil or balsam used to treat an infection of worms: 'This balsam works effectively against all the problems caused by worms.' There do not seem to have been any specific Scottish remedies for worms, apart from the general purging and restorative regimes, though the restoratives may have had regional variations in content.

I I. Balsamo o vero olio per le ferite: This translates as 'a genuine oil to treat wounds'.

12. Olio contro valeni: An oil to be used against poisons.

13. Elixir vite: An elixir of life. Various potions have been created over the centuries, each claiming to prolong life. The accompanying leaflet for this potion states: 'This is an elixir which works admirably to restore those weak or prostrated with illness, because it solaces and gladdens the heart, enhances natural warmth and bans decay.' It is assumed that this is an elixir vitae, a sweet preparation made with alcohol and more

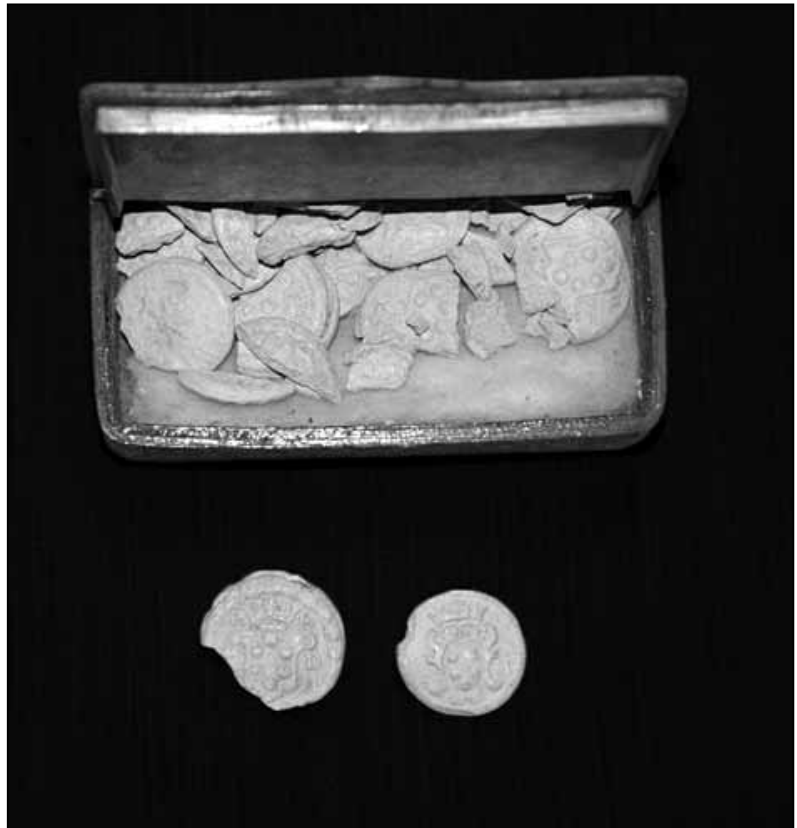

FIGURE $4 \mathrm{~A}$ tin box containing tablets embossed with the Medici arms.

frequently referred to in the literature as aqua vitae. The alcohol was usually produced by the distillation of red wine, although some formulas recommend the addition of herbs such as rosemary and sage. In this case it would most probably have been sweetened with syrup.

14. Polvere contro valeni: A powder to be used against poisons.

15. Terra sigillata: Literally translated as 'stamped earth', this is a medicinal clay from the island of Lemnos. It was formed into tablets and stamped with a distinctive seal, related to the place of origin. ${ }^{20}$ The clay was used both internally and externally against poisons and for dressing wounds. The container for this medicine is missing so we cannot determine whether this was a powder or a stamped tablet. Scottish historical records show that wounds were generally treated with various plasters (poultices) and soothing ointments, and often required lengthy periods of treatment with daily changes of dressings. ${ }^{21}$

16. Essenza di contraierva: This appears to be the same preparation as item number 3 (essence of contrayerva).

I7. Unguentum da fuoco: This is an ointment for burns. The leaflet states that 'this ointment works marvellously against all burns and scalds'. Burnett describes an ung. da fuoco de Capua, which he translates as 'Capuan ointment from fire'. ${ }^{22}$ He believes that this indicates that fire was probably used in preparing the ointment. According to the leaflet however, this preparation is an ointment to treat burns. The two may 
not be mutually exclusive though, as one approach to medical treatment in earlier periods (the doctrine of signatures) related to similarities, such as treating jaundice with yellow ointment, or burns with a preparation involving fire. The doctrine of signatures also held that herbs which looked similar to a part of the body could be effective in treating ailments relating to that part. Examples of this are lungwort, wormwood, spleenwort and bloodwort.

18. Olio da spasimo: An oil to cure spasms. The leaflet claims that the oil 'is wonderful in curing and removing the spasm, or convulsions of the nerves, as well as for prevention'.

19. Giulebbe perlato: Pearl julep.There are references in the literature to a number of prescriptions for a pearl julep ${ }^{23}$ which contained prepared pearl together with other herbs. The leaflet accompanying the julep is translated (p. 363) as an example of the literature found in the medicine chest.

While limited information is available on the ingredients used in the medicines, it is clear that they were issued in similar formulations - juleps, powders, pills, oils, waters and elixirs - to those in common use in Scotland in this period. The Medicis may have been able to produce pills and potions made from chemical processes, or which contained expensive ingredients, to a greater extent than was possible in Scotland, but there were still similarities. Hudson's examination of the contents of a Georgian medicine chest made in Britain noted familiar items such as rhubarb, jalap, ipecacuana and calomel. ${ }^{24}$ It would appear that while many items in both chests were similar, this was also something of a period of transition, with a move towards a greater proportion of chemical and mass-produced medicines.

It is difficult to ascertain whether any of the contents of the chest have been used. Some of the medicines have shrunk in their containers, but it is not possible to determine how much this was due to natural shrinkage over the centuries, or to usage. This chest is a rarity. Such items were produced as travelling chests, to provide medicines during often long periods away from home. It is possible that Clerk was given the chest because he was on his Grand Tour at the time and faced an arduous journey home.

\section{CONCLUSIONS}

The contents of this medicine chest give us some indication of the medicines that were in use in Italy at the time of its construction - or at least those available to members of the higher echelons of society. It is particularly interesting because it dates from the late seventeenth century, and medicine chests did not generally become available in Britain until the mideighteenth century. While it is possible to read all the names of the medicines in the chest, more research would be needed to clarify the contents of a number of these preparations. As many of the ingredients were treated as trade secrets by the manufacturing laboratory, it may be that the details of these formulae have been lost with time. It is clear from the limited information available that a number of the ingredients were common to Italy and Scotland and probably elsewhere in Britain and Europe, given the prevailing humoral medical philosophy. Medicines manufactured in bulk in laboratories using chemical processes appeared at different times throughout Europe, but it is clear that Sir John Clerk would have been familiar with a number of the contents of the chest and their uses.

Because we do not know the details of the formulae in most cases, it is not really possible to make a detailed comment or comparison of the drugs used in current practice. From what information we do have it can be said that this is a window into current practice at that time and that the complaints that were being treated are recognisable. Stomach complaints such as colic and indigestion, skin diseases and worms together with the treatment of burns and wounds are all catered for. More unusual are treatments for snake bites, kidney stone and aids to a longer life. Some products remained in use for many years; elixir proprietatis in one form or another, for example, was in use up to the 1930s. While it is difficult to compare the drugs from the medicine chest to modern medical practice, particularly following the discovery and introduction of sulphonamides and antibiotics, there are still enough common threads that connect them over time.

\section{Acknowledgements}

Grateful thanks are offered to Sir Robert Clerk for allowing us to examine the medicine chest in detail and to Renzo Console, not only for the translations of the Italian text, but also for researching the development of the Medici laboratory. The images are all courtesy of Sir Robert Clerk of Penicuik. 


\section{REFERENCES}

I Dingwall HM. A history of Scottish medicine: themes and influences. Edinburgh: Edinburgh University Press; 2003. pp. 72-108.

2 Hamilton D. The healers. A history of medicine in Scotland. Edinburgh: Canongate; 198I. pp. 4I-90.

3 Gentilcore D. Healers and healing in early modern Italy. Manchester: Manchester University Press; 1998.

4 Hudson E, editor. The grand tour 1592-1796. London: Folio Society; 1993.

5 Houston RA. Clerk, Sir John, of Penicuik, first baronet (1649/501722). Oxford Dictionary of National Biography. Oxford: Oxford University Press; 2004.

6 Mitchison R. Clerk, Sir John, of Penicuik, second baronet (I676-I 755). Oxford Dictionary of National Biography. Oxford: Oxford University Press; 2004.

7 Gray J, editor. Memoirs of the life of Sir John Clerk of Penicuik Baronet. Extracted by himself from his own journals 1676-1755. London: Nichols \& Sons; I895. p. 26.

8 Gray J, editor. Memoirs of the life of Sir John Clerk of Penicuik Baronet. Extracted by himself from his own journals 1676-1755. London: Nichols \& Sons; I895. p. 30.

9 Gray J, editor. Memoirs of the life of Sir John Clerk of Penicuik Baronet. Extracted by himself from his own journals 1676-1755. London: Nichols \& Sons; 1895. p. 29.

10 Scientific itineraries in Tuscany [Internet]. Medici Lodge in San Marco. Florence: Institute and Museum of the History of Science [cited 2012 Sept 19]. Available from: http://brunelleschi.imss.fi.it/itineraries/ place/CasinoMediceoSanMarco.html

II Paracelsus. Archidoxorum aureoli ph. Theophrasti paracelsi de secretis naturae mysteriis. Basel: perpetrum Pernam; I570.

12 Helmont J. A treatise of the great antidote of Van Helmont, Paracelsus, and Crollius by them called the elixir proprietatis, written by $\mathrm{JH}$, a lover of truth. London: the author; 1666.
13 Porter R. The greatest benefit to mankind. A medical history of humanity from antiquity to the present. London: Harper Collins; 1997. p. 125.

I4 Dingwall HM. Physicians, surgeons and apothecaries. Medical practice in seventeenth-century Edinburgh. East Linton: Tuckwell Press; 1995. Pp. 199, 210.

15 Hodges N. Loimologia, or an historical account of the plague in London. London in 1665. London: Bell; 1721.

16 Donzelli G. Teatro farmaceutico dogmatico e spagirico. Venice:Andrew Poletti; I68I. p. 502

17 Hibbert C. The rise and fall of the House of Medici. London: Penguin Books; 1979.

18 Griffin JP. Venetian treacle and the foundation of medicines regulation. $\mathrm{Br} J$ Clin Pharmacol 2004; 58:317-25. http://dx.doi. org/I0.IIIII/j.1365-2I25.2004.02I47.x

19 Wootton AC. Chronicles of pharmacy. London: Macmillan \& Co; 1910. pp. 42-50.

20 Thompson CJS. The mystery and art of the apothecary. London: John Lane; 1929. p. 44.

21 Dingwall HM. Physicians, surgeons and apothecaries. Medical practice in seventeenth-century Edinburgh. East Linton:Tuckwell Press; 1995. pp. 150-2; 173-4.

22 Burnett J.The Giustiniani medical chest. Med Hist I 982; 26:325-33.

23 Quincy J. Pharmacopoeia officinalis extemporanea or a compleate English dispensatory. London:T Longman. p. 540.

24 Hudson B. A Georgian first aid cabinet: unpacking an early 19th century medicine chest. Pharm Hist 2006; 36:37-43. 